\title{
Theorising the Interconnectivity between Corporate Social Responsibility (CSR) and Corporate Identity
}

\author{
Olutayo Otubanjo ${ }^{1}$ \\ ${ }^{1}$ Lagos Business School, Pan-African University, Lagos, Nigeria \\ Correspondence: Olutayo Otubanjo, Km 22 Lekki Epe Expressway Ajah, Lagos, Nigeria. Tel: \\ 234-808-608-6816. E-mail: totubanjo@lbs.edu.ng
}

Received: July 21, $2012 \quad$ Accepted: August 27, $2012 \quad$ Online Published: October 9, 2012
doi:10.5539/jms.v3n1p74

\begin{abstract}
Corporate social responsibility (CSR) and corporate identity (CI) concepts have grown over the years as distinct bodies of knowledge with seemingly divergent objectives. The recent rise in corporate social reporting among national and multinational business organisations suggests that both concepts have more in common that unite than divide them. This paper explores theoretical literature concerning the meaning of corporate identity and CSR, fusing these theoretical discourses into a cohesive construct - "CSR Identity". It develops a working definition for the construct and explores the research and managerial implications of this emergent construct in relation to business competitiveness. It is hoped that this study will extend the current discourse in both $\mathrm{CI}$ and CSR and provide an innovative approach for constructing CSR Identity for firms in the business environment.
\end{abstract}

Keywords: corporate social responsibility, corporate identity, CSR identity, construct, corporate communications, social reporting

\section{Introduction}

Corporate social responsibility (CSR) has become a buzz word and an important business practice (Ker-Tah, 2012; Cai et al, 2012; Bakker et al., 2005; Burchell and Cook, 2006; Lepoutre and Heene, 2006; Driver, 2006; Siltaoja, 2006) especially in profit oriented firms. The core idea behind CSR is the promotion of business orientation that takes stakeholder interests into account (see Maignan et al. 2005; Fry and Polonsky, 2004). CSR is driven by the philosophy that businesses are part of the society and as such ought to contribute positively to social goals and aspirations (Jones, 2005). In this regard, some CSR proponents argue that businesses should be held accountable (Maignan et al. 2005) not only for their economic responsibilities to shareholders, but also for the non-economic consequences of their activities on the society and the natural environment (Robins, 2005). As a result, businesses have begun to accord high value and importance to responsible behaviour (Assadourian, 2006). There is mounting evidence indicating that firms now invest heavily and ceaselessly on CSR. For instance, in year 2005 alone, over \$US3.6 billion was committed voluntarily by business organisations to CSR activities (Phillips, 2006). Yet the amount of charitable and philanthropic contributions made by businesses to society continues to rise (Renz and Lawrence, 2005).

As interest in CSR grows, so has the value and importance attributed to corporate identity (Abratt and Kleyn, 2012; Soti et al, 2009; Shu-pel Tsai, 2008; Balmer and Greyser, 2006; He and Balmer, 2005; Balmer and Greyser, 2003; Balmer, 2001). In practice, the number of firms requiring corporate identity services is rising (see Schmidt, 1995) and the amount of financial and material resources committed to corporate identity practices is growing by the day (see Olins, 1995). In addition, the amount of attention paid in literature to this burgeoning discipline has grown phenomenally (Wallace et al, 2006; Melewar et al. 2006; Suvatjis and de Chernatony, 2004). The increased number of literatures devoted to this field provides strong evidence in this regard (Balmer, 2001).

Without any doubt, the vast resources committed to corporate identity and CSR practices (see Schmidt, 1995; Grayson and Hodges, 2004) is reflective of the relevance, growth and importance of these two disciplines. More importantly, the surge in the number of corporate scandals such as nuclear power disaster in Russia (Hussey, 1998); dismantling of oil rigs in the North Sea (Fombrun and Rindova, 2000); escape of poisonous gas from a chemical plant in India (Hussey, 1998); sudden and untimely collapse of big businesses and increased pressure from stakeholders, which have profound effects on business and corporate reputation have undoubtedly 
positioned corporate identity and CSR as a legitimate business practice in the contemporary world of work (see Perrini, 2006). The increased drive towards corporate identity and CSR is made more evident by the rising volume of corporate identity literatures (i.e. social reports), which has continued to generate the interest among big multinational businesses (see Kolk, 2005; Gond and Herrbach, 2006).

In the past, many firms with little or no corporate identity communications drive (Salu, 1994) and no CSR and social advocacy voice (see Borgoon et al. 1995; Schumann et al. 1991) now devote enormous resources not only to the pursuit of CSR but also towards accounting for their CSR stewardship. According to Whitehouse (2006, p. 279), "The inclusion of a few paragraphs within the annual report dealing with the non-financial aspects of the business has been replaced by the publication of glossy reports and a high profile presence on corporate websites of 'CSR' issues". The presentation of business stewardship in the form of social and environmental reports is a strategic resource (see Owen et al., 2000) highlighting the integration of CSR with strategy (see Burke and Logsdon, 1996; Swanson, 1999) and the important role of CSR in overall corporate strategy (Dawkins and Lewis, 2003).

Furthermore, the rise in business competitiveness together with the desire by firms to develop a strong and impeccable corporate reputation has provoked a change in the ways that businesses approach these disciplines. Many firms are conscious of the need to exhibit their CSR activities through their corporate identity (see Maignan and Ralston, 2002; Esrock and Leichty, 1998; Hooghiemstra, 2000; Adams et al. 1998). Hence, evidence is emerging from the industry that firms are increasingly integrating the management of these 2 disciplines into one cohesive role. Consequently, new management functions such as Corporate Affairs and Responsibility Manager, Corporate Regulatory Affairs Manager etc, which fuses these two management concepts into a single business management function, is emerging.

Despite the increased drive towards the integration of these concepts, there is very little evidence to demonstrate that this subject has been thoroughly investigated. Consequently, very little is known about how these two disciplines interrelate.

Against this backdrop, the present study has been designed mainly to address this issue. Specifically, we demonstrate how CSR can be effectively entwined with another important business phenomenon - corporate identity. The study begins with the review of theoretical literature concerning the meaning of CSR and corporate identity and a theoretical framework synthesising corporate identity and CSR is designed. The converging aspects of this framework are highlighted to prelude the development of a new conceptual definition, underscoring the emergence of a new construct - CSR identity. In the second section, a discussion emphasizing theoretical and managerial implications of this emerging construct for business competitiveness is put forward and the study is summarised and concluded in the third section of this study.

\section{Literature Review}

\subsection{Corporate Identity (CI): What It Means}

Over 40 definitions (see Appendix) explaining the meaning of corporate identity has been contributed by academic and practitioner authors. The review of these definitions reveals six distinct (thematic) notions of corporate identity (see Figure 1 below). These are "who or what the firm is"; "where the firm is going", "how different the firm is", "what the firm does", "how the firm carries out its business" and "what the firm stands for". These notions are discussed as follows: 


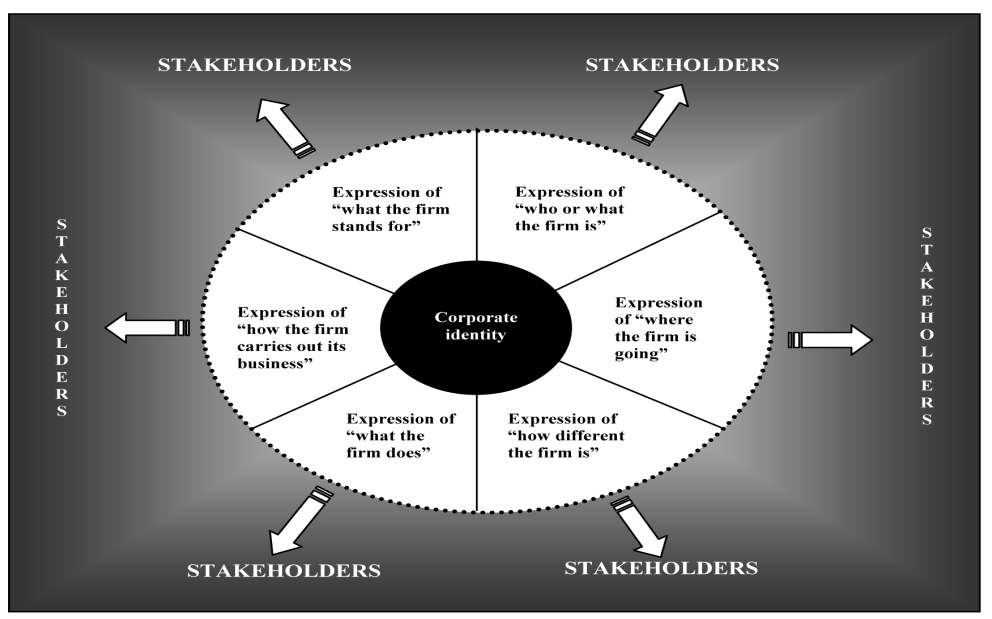

Figure 1. Notions of corporate identity

Source: developed by author

\section{Notion 1: corporate identity as the expression of "who or what the firm is"}

The notion of "who or what the firm is" has appeared in several definition of corporate identity (see Selame and Selame, 1975; Hawn, 1998 Topalian, 1984; Downey, 1986; Portugal and Halloran, 1986). Of these Selame and Selame's (1975) definition is the first to make reference to this conceptual theme. As Selame and Selame (1975) observes, corporate identity is a firm's statement describing "who and what the firm is" to stakeholders. The notion of expression of "who and what the firm is" in Selame and Selame's (1975) definition refers to the expression and the communication of the features that underscore the very essence of a firm. It is a critical aspect of corporate personality (see Lux, 1986; Antonoff, 1985; Balmer, 1993; Hawn, 1998; Leitch, 1999; Dolphin, 1999) reflective of the innate, actual and basic traits as well as other phenomenon that makes up, signify and define firms. The fundamental idea driving this notion urges managers to make genuine and conscious effort to review and communicate the core traits and innate characteristics inherent in their firms. Such a review and expression is a precondition for establishing the major factors that define the essence of the firms (see van Rekom, 1997).

Notion 2: corporate identity as the expression of "where the firm is going"

Halloran and Portugal (1986) and Downey (1986) extended the boundaries of Selame and Selame's (1975) definition of corporate identity, incorporating the notion of "where the firm is going". In Portugal and Halloran (1986) view, corporate identity is a strategic component containing series of activities expressing or projecting "where the firm is going" (Downey, 1986). The expression of "where the firm is going" highlights the strategic intent (see Hamel and Prahalad, 1989), the corporate vision or what Balmer (2001) described as the desired corporate identity or the desired future at which the company hopes to arrive (Melewar, 2003). The basic philosophy underscoring this notion of corporate identity is that the corporate vision or desired corporate identity, articulated in the minds by Chief Executive Officer (Balmer, 2001) must be effectively communicated to all employees.

\section{Notion 3: corporate identity as the expression of "how the firm is different"}

The notion of "how different the firm is" has been documented in Portugal and Halloran's (1986) and Gioia's (1998) definition of corporate identity. For Portugal and Halloran (1986) corporate identity is strategic asset communicating three things: "what a firm is", "where the firm is going" and "how it is different". Gioia (1998) agreed with Portugal and Halloran (1986) stating that corporate identity is a phenomenon reflective of three things: what is taken by the firm, what makes firms unique and what is conceived by members to be enduring. Importantly, the notion of "how the firm is different" (Portugal and Halloran, 1986) or "what makes the firm unique" (Gioia, 1998) is indicative of the characteristics that distinguish (see Schmidt, 1995; Lambert, 1989; van Riel and Balmer, 1997; Balmer and Soenen, 1997; Gray and Balmer, 1998) firms from others with similar business inclinations. The fundamental idea behind this notion is that firms must review, identify and communicate the core characteristics that encapsulate the core identity that differentiate them from competitors. Furthermore, firm must capitalise on unique skills that define the firm (Melewar, 2003). 
Notion 4: corporate identity as the expression of "what the firm does"

Topalian's (1984) definition of corporate identity drew attention to the notion of "what the firm does". In his definition Topalian (1984) declared that corporate identity is synonymous with three things. First, is "what the firm is", second is "what the firm stands for" and third is "what the firm does". The notion of what the firm does, which is being addressed under this paragraph has been highlighted previously in Olins (1995) definition of corporate identity. In his definition, Olins (1995) affirmed that the concept of corporate identity underscores daily business activities carried out by firms. As he observed firms carry out thousands of activities daily. They buy, sell, hire, fire, advertise, compete etc. In the course of these activities as Olins (1995) argues, businesses will in some way present themselves or communicating their corporate identity (wholly or partly) to stakeholders (Olins, 1995). Importantly, the basis of this notion is that in the course of carrying out various business activities, firms convey messages about their corporate identity or "what the firm does" to stakeholders.

Notion 5: corporate identity as the expression of "how firms carry out businesses"

The notion of 'how the firms carry out businesses' has been drawn from Olins (1995) definition of corporate identity which refers to corporate identity as the "how firms carry out their businesses". How firms carry out businesses is a function of the strategy process (see Mintzberg and Quinn, 1996). It could be viewed as the strategy deployed by firms in accomplishing set corporate objectives and business goals. It is the master plan circumscribing firm's product, market scope, objectives, (Melewar, 2003). It is the policies through which the company competes in its chosen markets (Gray and Balmer, 1998). Kiriakidou and Millward (1999) argued that corporate strategy plays a significant role in the articulation of corporate identity. Marwick and Fill (1997) also argued that corporate strategy is a significant component of corporate identity mix. Similarly, Stuart (1998) contends that corporate identity is a manifestation of corporate personality based on corporate strategy. The importance of this notion is that firms must fully articulate their corporate and operational strategy. This enhances the development of a clear corporate identity management process.

Notion 6: corporate identity as the expression of "what the firm stands for"

Topalian (1984) linked the concept of corporate identity to "what businesses stands for" and argued that corporate identity is a strategic asset largely under the control of the host firm. The notion of "what the firm stands for" in Topalian (1984) definition reflects a set of principles, philosophy, values and system of ethics that drives businesses and commonly shared by members of a firm. Balmer (1995) defined corporate philosophy as the business mission and values espoused by the management board or the founder. Bernstein's (1984) linkage of corporate philosophy and corporate identity arose out of his belief that corporate identity serves as a vehicle for expressing the company's philosophy (Abratt, 1989). While corporate philosophy embodies core corporate values and assumptions constituting corporate culture (Abratt, 1989), corporate value, are the beliefs and moral principles that lie behind the company's culture (Melewar, 2003). Values are domineering beliefs comprising business language unique to the firm, ideologies and rituals of personnel. This forms a significant proportion of the corporate personality and corporate identity (van Riel and Balmer, 1997). Importantly, the fundamental principle driving this idea is that firms must establish a system of philosophies and core values that can be embedded into the ways of life of the firm and communicated to stakeholders.

\subsection{The Meaning of CSR}

The review of literature on the meaning of CSR reveals four significant but divergent viewpoints represented in Figure 2. These include CSR as "what is socially expected of the firm", CSR as "what the firm does for stakeholders", CSR as an ethical business practice and CSR as a business resources or strategic business activity". 


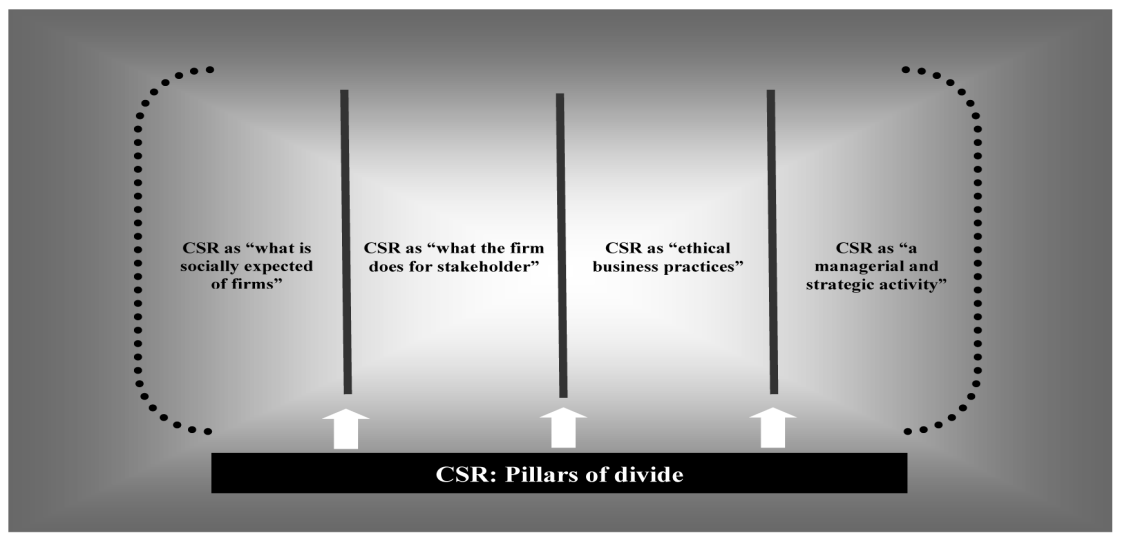

Figure 2. Quartochotometric divide over the meaning of CSR

Source: developed by author

\section{Viewpoint 1: CSR as "what is socially expected of the firm"}

The "what is socially expected of the firm" viewpoint constitutes the first theoretical review on the meaning of CSR in this study. It concerns all social expectations of businesses as demanded by stakeholders. Describing this viewpoint as ethical CSR, Lantos (2001) argued CSR concerns the demand by the society for firms to pursue their business activities in such a way that prevent injury and bodily harm. This type of CSR is demanded by the society and must be fulfilled by all firms. Bowen's (1953) text, which approached the meaning of the concept from the social expectations of businesses perspective, provides the first known definition for CSR and his definition fits perfectly into this viewpoint. In his definition, Bowen (1953) argued that modern firms must be challenged by the urge to satisfy social obligations as demanded by the society. As Bowen $(1953$, p. 6) observed, CSR "refers to the obligations of businessmen to pursue those policies, to make those decisions, or to follow those lines of action which are desirable in terms of the objectives and values of our society." Buttressing this view, Carroll (1991) observed that further that the notion of CSR involves all economic, legal, ethical and philanthropic expectations placed on firms by society (see also Carroll and Buchholtz, 2002). In similar vein, The Business for Social Responsibility (BSR) averred that CSR refers to conscious decisions by businesses to consistently meet and exceed the ethical, legal, commercial and public demands of stakeholders and the societies in which businesses operate. Whetten et al. (2002) definition of CSR also added voice to the social obligatory demands on businesses. According to Whetten et al. (2002, p. 374) CSR is the "societal expectations of corporate behaviour; a behaviour that is alleged by a stakeholder to be expected by society or morally required and is therefore justifiably demanded of a business". Corroborating, De George (1999) declared that CSR is also used to represent social obligations imposed on businesses by the society.

\section{Viewpoint 2: CSR as "what the firm does for stakeholders"}

The second viewpoint dominating the literature on the meaning of CSR relates to duties, decisions, actions and responsibilities carried out voluntarily or forced on firms as a strategic approach towards profit making. These voluntary or forced actions (see Lantos, 2001) may be in the form of responsible business behaviour, discharge of legal obligations to stakeholders, pursuit of social good and socioeconomic contributions to the society. Several CSR definitions have highlighted this viewpoint. For instance Vos (2003) definition of CSR underscored socioeconomic and legal duties and actions carried out by the firm for stakeholders. He argued that CSR are business, ethical, economic and legal obligations carried out by firms for stakeholders. Similarly, The World Business Council for Sustainable Development (WBCSD, 1999) definition of CSR laid emphasis on ethical actions, responsible business behaviour and socioeconomic contributions to the society. For WBCSD (1999) CSR refers to the decision by firms to behave ethically and responsibly, contribute to socioeconomic development of the society while (at the same time) improving and enhancing the quality of life of stakeholders and the community in which businesses operate (WBCSD, 1999). Actions taken by firms in relation to CSR have been reiterated in McWilliams and Siegel's (2001) definition of CSR. According to them CSR are those "actions that appear to further some social good, beyond the interests of the firm and that which is required by law" (McWilliams and Siegel, 2001 p. 117). World Bank's (2004) definition of CSR also stressed the role of firms in contributing towards the society. In World Bank's view, CSR is the contribution made by businesses towards sustainable economic development. It is reflection the decision by businesses to work with stakeholders and 
enhance the standards of lives for the good of businesses and society. The European Union (EU) definition of CSR also stressed "what the firm does for stakeholders" in the form of actions taken towards the integrating CSR into all business activities. For the European Union (EU) CSR is a concept used by firms to integrate social and environmental concerns in their business operations and in their interaction with stakeholders on a voluntary basis' as they are increasingly aware that responsible behaviour leads to sustainable business success.

Viewpoint 3: CSR as "ethical business practices"

Authors under this viewpoint addressed CSR as a series of activities that firms pursue for its own sake rather than for the sake of profit making. Proponents of this theory argue that firms must pursue CSR genuinely with no intention to profit. They argue that firms must be socially responsible because it is the noble thing to do. Davies and Blomstrom's (1966) definition of CSR reflects this viewpoint. They contend that CSR should be pursued as firms' obligations to consider the effect of their business activities and actions on the society and the natural habitat. They argued that firms adopt CSR only when the needs and interests of stakeholders are duly considered beyond the firm's business, economic and technical interest. This viewpoint is also supported by Davies (1967). He argued that the substance in CSR arises from the genuine concern for the ethical outcomes of all business activities as they affect the interest of the firm's stakeholders. Corroborating, Johnson (1971) averred that a CSR oriented firm is one that is genuinely interested not only in its own well being but also in the welfare of its employees and others in the society.

Viewpoint 4: CSR as "a managerial and strategic business activity"

The use of CSR as a strategic business activity has been emphasised in theoretical literature. Essentially, the strategic CSR occurs when firms pursue specific community projects that exhibit the firms' care for the society on the one hand and aid the accomplishment of strategic business goals (see Lantos, 2001) on the other. Walton's (1967) definition of this concept expresses this idea. He argued that in order to be seen as being CSR oriented, firms must recognise the intimate relationship between themselves and their host community and that such relationships must be kept in the minds of senior managers in the pursuit of all business activities.

\subsection{Corporate Identity and CSR: Working Definitions}

The review of literature on the meaning of corporate identity in the paragraphs above revealed six distinct (thematic) notions of corporate identity namely "who or what the firm is"; "where the firm is going", "how different the firm is", "what the firm does", "how the firm carries out its business" and "what the firm stands for". Similarly, the review of CSR literature indicate the dominance of four central viewpoints namely "what is socially expected of the firm"; "what the firm does for stakeholders", "CSR as an ethical business practices" and "CSR as a managerial and strategic business activity". Of these however, we adopt the notion of "what the firm does", which underscores daily business activities carried out by firms (see Olins, 1995) and "what the firm does for stakeholders" as our working definitions for corporate identity and CSR respectively. This is because the notion of "what the firm does" is closely related (see figure 3) to the "what the firm does for stakeholders" viewpoint, reflective of WBCSD (1999) definition of CSR, which highlights the functional role of firms in relation to the pursuit of CSR. This includes the need to behave ethically and responsibly, the importance of discharging legal obligations, contribution to social good and socioeconomic development of the society while (at the same time) improving and enhancing the quality of life of stakeholders and the community in which businesses operate (see WBCSD, 1999). In the following paragraphs, we explore the links between the meanings of CSR and corporate identity and then integrate these two concepts into one synergetic construct. 


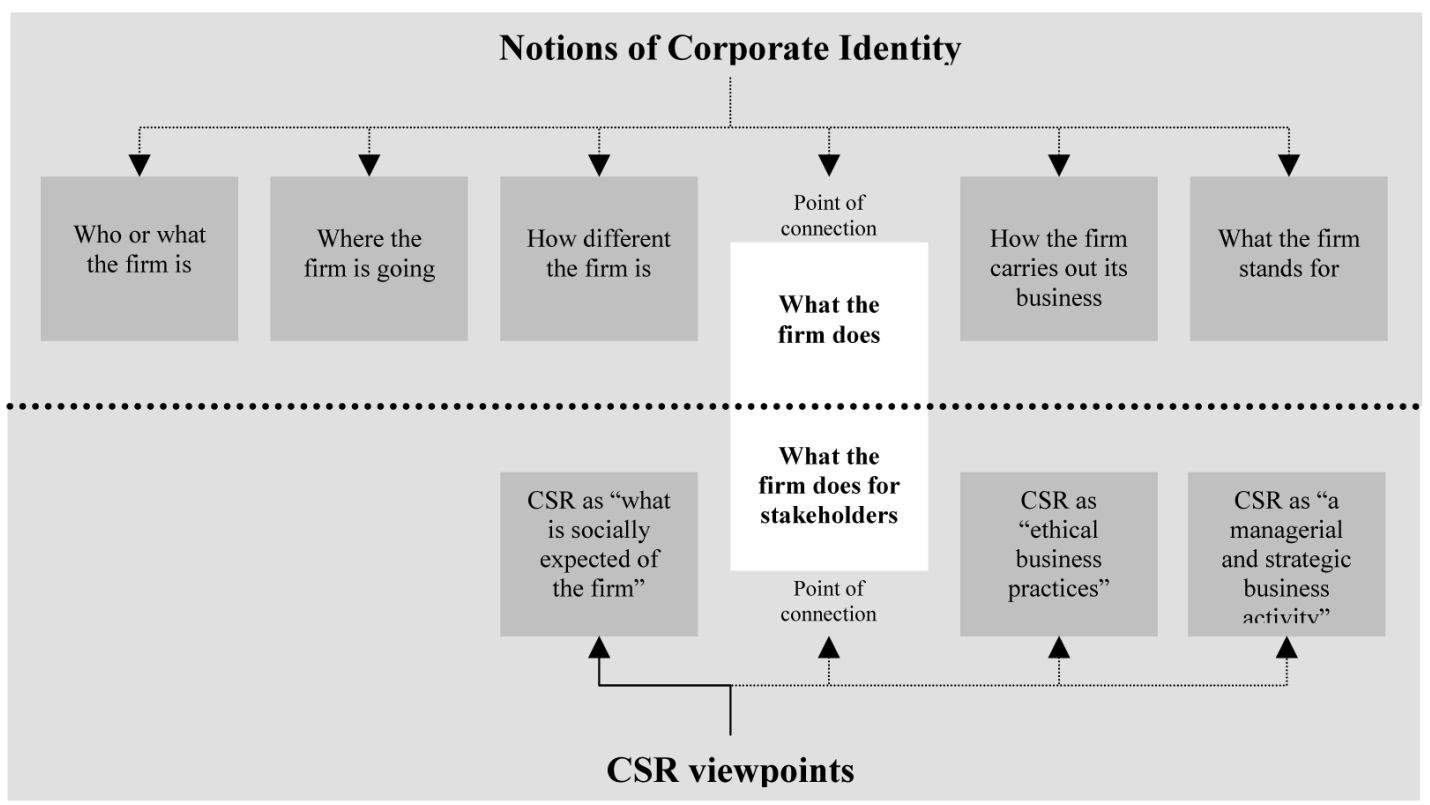

Figure 3. Point of connection between the meaning of CSR and corporate identity

Source: developed by author

\subsection{Point of Connection: Expression of "What the Firm Does" and "What the Firm Does for Stakeholders"}

2.4.1 Strand 1: Expression of "What the Firm Does"

The notion of "what the firm does" (see Topalian, 1984) relates to the daily business activities carried out by firms, (see Olins, 1995). Everyday, firms carry out multifaceted activities including buying and selling, hiring and firing, supply and procurement etc (see Figure 4 below) through various units or departments (i.e. marketing, finance, corporate communications and production.

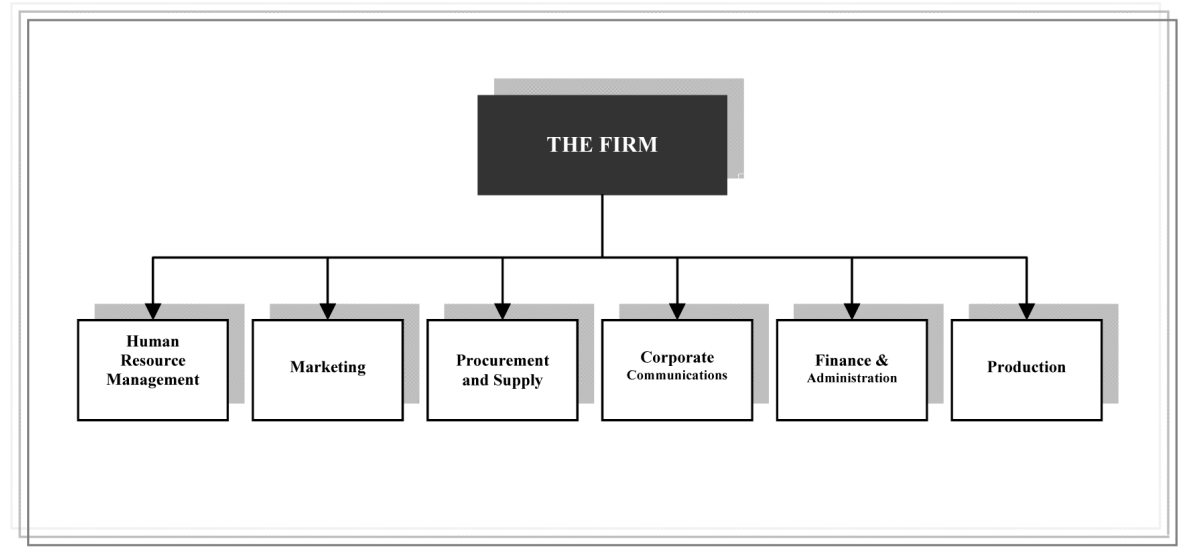

Figure 4. Firm's departments

Source: developed by author

The pursuit of these activities through these departments enables firms to secure benefits of specialisation (see Heinz et al. 2006; Schoemaker and Amit, 1994). 


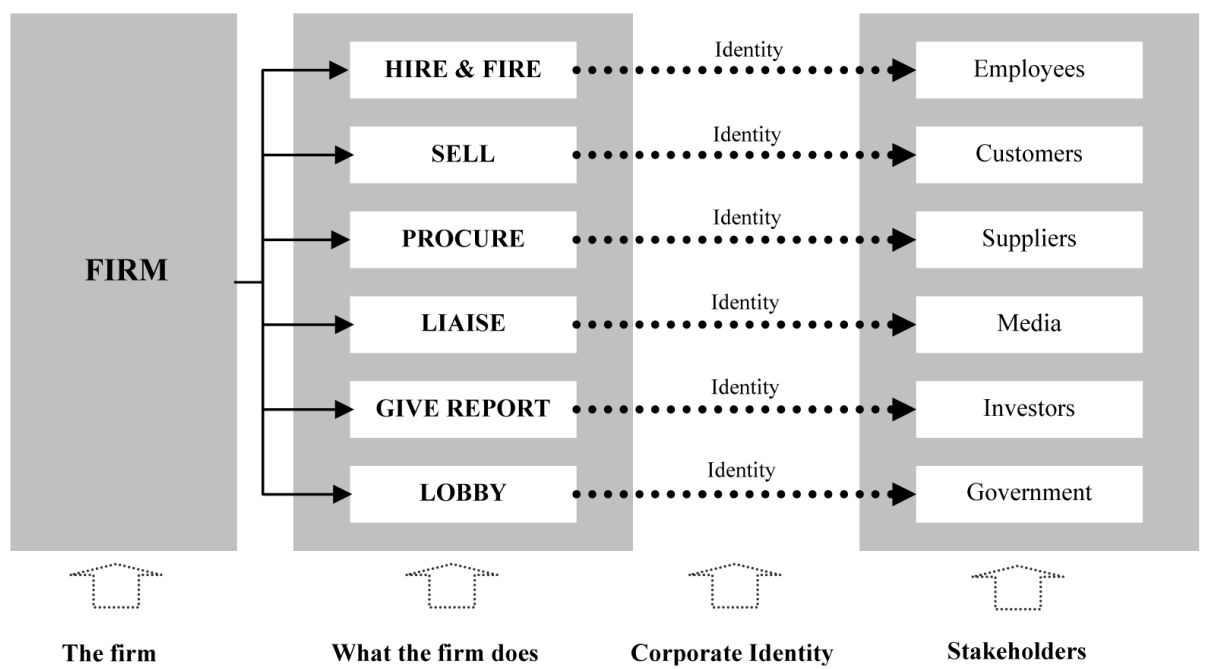

Figure 5. Expression of "what the firm does"

In the course these activities, firms present their corporate identity (partly or wholly) to stakeholders (Olins 1995). This is aptly demonstrated in Figure 5. In the paragraphs that follow, an attempt is made to discuss some of the multifarious activities through which the corporate identity is conveyed to stakeholders.

It has been argued that a firm's performance is greatly enhanced by human resources practices, (Huselid, 1995; Cutcher-Gershenfeld, 1991; Arthur, 1994; Huselid and Becker, 1996). The role of human resource department in firms therefore is to design and implement a set of internally coherent policies and practices that will enhance competitiveness (see Barney and Wright, 1998) and the achievement of the strategic goals of the firm (Huselid, 1997). Specifically, the human resources department is chiefly responsible for recruitment and selection of job applicants, design of organisation structure and job description, training and development of employees, employee performance management and cultural and interpersonal skills training (Rajhi et al. 2006). Marketing departments are primarily designed to drive the marketing function of the firm (Grönroos, 1997). Together with other stakeholders (see Olasz, 2006) such as advertising agencies, market analysis consultants, marketing departments identify customer needs (Griffin and Hauser, 1993), design frameworks to meet these needs (Jaworski and Kohli, 1993) and develop suitable positioning strategies (see Ries and Trout, 1986) for company products. Marketing departments are also charged with the responsibility of product sale and distribution, attending to customer queries, managing after sales services, developing advertising campaigns, and the management of the customer-firm relationship interface (Doyle, 1995; Olasz, 2006).

The role of the purchasing and procurement department is to manage the delivery of goods and services from suppliers in a cost effective manner (Johnson et al. 2003). Like other functional departments, the purchasing department play a strategic role in the overall success of the firm, (Humphreys et al. 1998) as it serves as the point through which all production materials are sourced. The contributions of the purchasing department among other things include the purchase of raw materials, planning and control of raw materials within the firm, disposal of scraps and surpluses, control of product inventory, taking delivery of purchased materials, managing outbound traffic, monitoring in plant material movement (Johnson, 2003).

The corporate communications department plays a key role in the management of firm - stakeholder relationships (Goodman, 2000) and it is a vital management function in modern firms (van Riel, 1995). It is concerned with total process of identifying, establishing and maintaining long-term relationships with stakeholders (Dolphin, 2003). The corporate communication department is saddled with the responsibility of managing community development projects, lobbying government officials, drawing up annual reports as well as carrying out media, investor and employee relations (Goodman, 2006) activities. It is the responsibility of this department to liaise with the press and other strategic stakeholders to develop good working relationships and secure legitimacy (see Deephouse and Carter, 2005). 


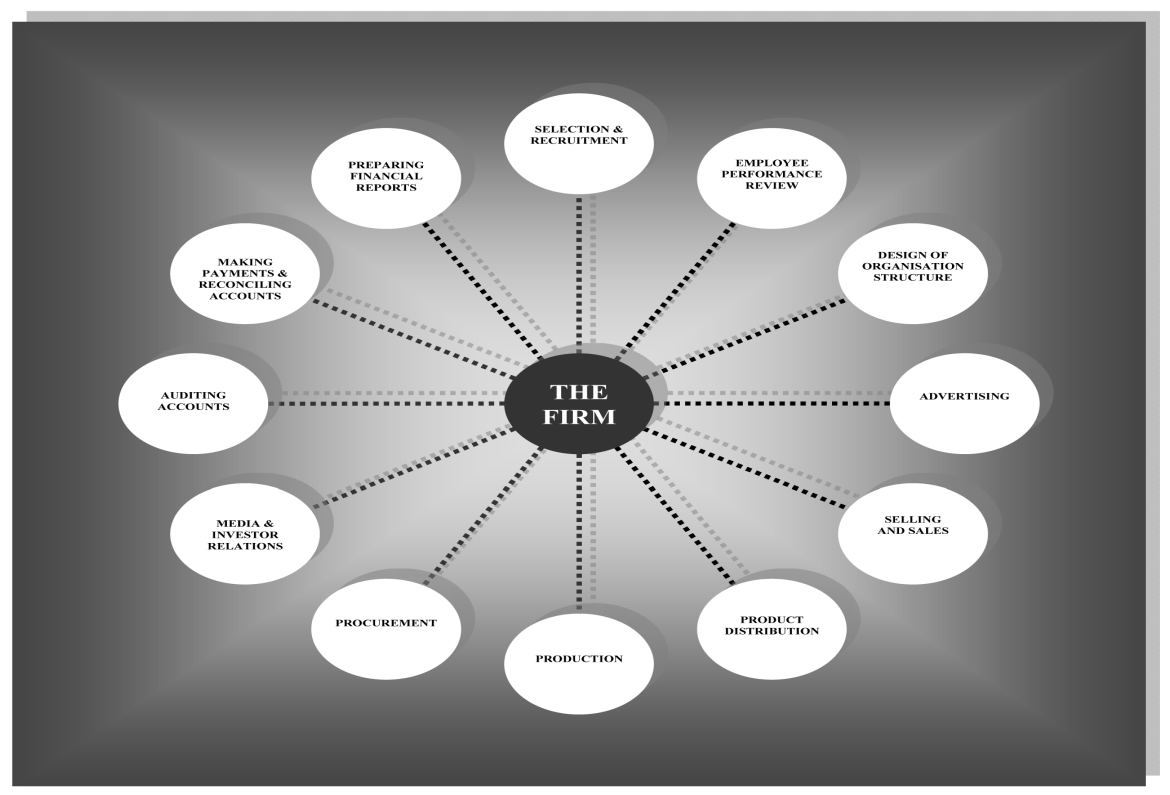

Figure 6. Activities of the firm

Source: developed by author

In many firms, finance and administrative functions are lumped together. Most often this department is responsible for managing and maintaining a general accounting system, investing cash reserves, administering payroll, preparing and administering the firm's annual budget, advice financial advice to management. This department is also responsible for reconciling bank accounts, preparation of various financial reports and in some cases auditing company accounts (Anonymous, 2007).

Production departments are designed to combine raw materials together and turn into finished and sellable goods through a series of production processes. The production department is charged with the sole responsibility of setting production standards and targets for each section of the production process. For this reason, the quantity and quality of products emerging from each production line is closely monitored (Anonymous, 2007)

\subsubsection{Strand 2: What the Firm Does for Stakeholders}

"What the firm does for stakeholders" refers to the responsibilities of the firm in relation to its action and duties towards employees, customers, suppliers, media, investors, government and local community (see table 1.1). Carroll and Buchholtz (2006) identified four core responsibilities including economic, legal, ethical and philanthropic. Figure 6 (above) gives a visual notion of these responsibilities, which are discussed in the paragraphs below:

\section{Economic responsibility of the firm to stakeholders}

Carroll and Buchholtz (2006) contend that the primary role of the firm is to be an economic institution with the orientation to produce goods and services profitably at prices reasonable enough to keep the firm perpetually, grow and reward investors. Importantly, firms that pursue this form of corporate social responsibility often aim to offer their goods and services for sale at a price that (1) represents its true value; (2) ensures the perpetuation of the business or firm; (3) enhances the delivery of products; and (4) at a price that ensures growth and business profitability. In the course of pursuing these socioeconomic responsibilities, firms deploy various business and management concepts aimed at maximising and enhancing the firm's long-term financial performance (Carroll and Buchholtz, 2006). 
Table 1. What the firm does for stakeholders

\begin{tabular}{|c|c|c|}
\hline FIRM & STAKEHOLDERS & WHAT THE FIRM DOES FOR STAKEHOLDERS \\
\hline & $\begin{array}{l}\text { Selection \& } \\
\text { recruitment }\end{array}$ & $\begin{array}{ll}\text { - } & \text { Ensure applicants' safety during recruitment } \\
\text { - } & \text { Give financial assistance to applicants from afar } \\
\text { - } & \text { Adhere to recruitment laws } \\
\text { - } & \text { Give equal employment opportunities } \\
\text { - } & \text { Give reasonable selection tests }\end{array}$ \\
\hline & Selling $\&$ sales & $\begin{array}{ll}\text { - } & \text { Ensure product safety } \\
\text { - } & \text { Provide goods which satisfy quality expectations } \\
\text { - } & \text { Control of environmental impacts of products } \\
\text { - } & \text { Offer high quality good to customers } \\
\text { - } & \text { Sell products at a price that represents its true value; perpetuate } \\
\text { firm; enhance efficient delivery of products and also at a price } \\
\text { that assures growth and business profitability } \\
\text { - Control of ethical and social aspects of products } \\
\text { - } \quad \text { Observe all competition laws }\end{array}$ \\
\hline & Procurement & $\begin{array}{ll}\text { - } & \text { Purchase green/eco friendly raw materials } \\
\text { - } & \text { Give suppliers equal opportunities } \\
\text { - } & \text { Appoint suppliers that respect laws \& social norms } \\
\text { - } & \text { Engage suppliers with green management record } \\
\text { - } & \text { Encouraging adherence to procurement law } \\
\text { Appoint suppliers with good delivery record }\end{array}$ \\
\hline \multirow[t]{4}{*}{ The firm } & Production & $\begin{array}{ll}\text { - } & \text { Recycle wastes } \\
\text { - } & \text { Produce good commensurate to specified prices } \\
\text { - } & \text { Ensure total quality in all production processes } \\
\text { - } & \text { Observe health and safety policies during production }\end{array}$ \\
\hline & $\begin{array}{l}\text { Media \& investor } \\
\text { relations }\end{array}$ & $\begin{array}{l}\text { - } \quad \text { Provide accurate information to investors and media } \\
\text { - } \quad \text { Declare dividends when due } \\
\text { - } \quad \text { Provide honest media and investor communications } \\
\text { - } \quad \text { Give only facts that can be substantiated }\end{array}$ \\
\hline & Financial matters & $\begin{array}{ll}\text { - } & \text { Maintain accurate \& reliable financial records always } \\
\text { - } & \text { Remit taxes when due } \\
\text { - } & \text { Refrain from tax evasion or tax avoidance } \\
\text { - } & \text { Comply with state rules and regulations } \\
\text { - } & \text { Protect \&respect confidentiality of financial matters }\end{array}$ \\
\hline & Advertisement & $\begin{array}{l}\text { - Avoid messages that may mislead audiences } \\
\text { - } \quad \text { Advertisements must state true conditions of products } \\
\text { - } \quad \text { Advertising copies must observe all competition rules } \\
\text { enacted from time to time }\end{array}$ \\
\hline
\end{tabular}

Source: developed by author

\section{Legal responsibility of the firm to stakeholders}

The legal responsibilities of a firm refer to societal view of "codified ethics", which embody basic notions of fair practices as established by law makers (Carroll and Buchholtz, 2006, p. 35). Firms exhibit their responsibility and respect for these laws by complying with all laws ranging from those regulating financial matters to the advertisement of goods and services. Firms that do not agree with existing laws or laws about to be passed can challenge them by getting involved in the political process and sponsoring bills through designated members of parliament.

Ethical responsibility of the firm to stakeholders 
Ethical responsibilities of the firm encompass activities and practices that are either prohibited or expected of firms despite the fact that these activities are not legally binding on firms. Ethical responsibilities embody the full scope of norms, standards reflective of what stakeholders regard as morally right, just and fair (Carroll and Buchholtz, 2006). Ethical responsibilities or activities of the firm include offering equal opportunities to all job applicants irrespective or religion, sex, age or race. It may involve the resolve by a financial institution to refrain from accepting deposits from political leaders who cannot give a true account of the source of their wealth.

Philanthropic responsibility of the firm to stakeholders

This aspect of corporate social responsibility is very common among firms. Philanthropic responsibilities are voluntary and non mandatory activities carried out by firms in their desire to assist the needy and the less privileged. It is also pursued to support social institutions such as universities, hospitals etc operating within the host community. Philanthropic gestures by firms to the society may include financial donations to the needy, sponsorship of sports festivals, scholarships etc. (Carroll and Buchholtz, 2006).

\subsubsection{Integration of Strands 1 and 2}

Figure 7 (below) brings together the concepts of CI (what the firm does) and CSR (what the firm does for stakeholders) together explicating the link and relationship between them. The integration of CI and CSR begins with the articulation of "what the firm does" (i.e. buying, selling etc) and "what the firm does for stakeholders" (i.e. pursuit of socially responsible behaviour). These distinct strands are then integrated through policy making. Figure 8 (below) supports Figure 7 by shedding light on the integration of corporate identity activities and CSR activities pursued by firms.

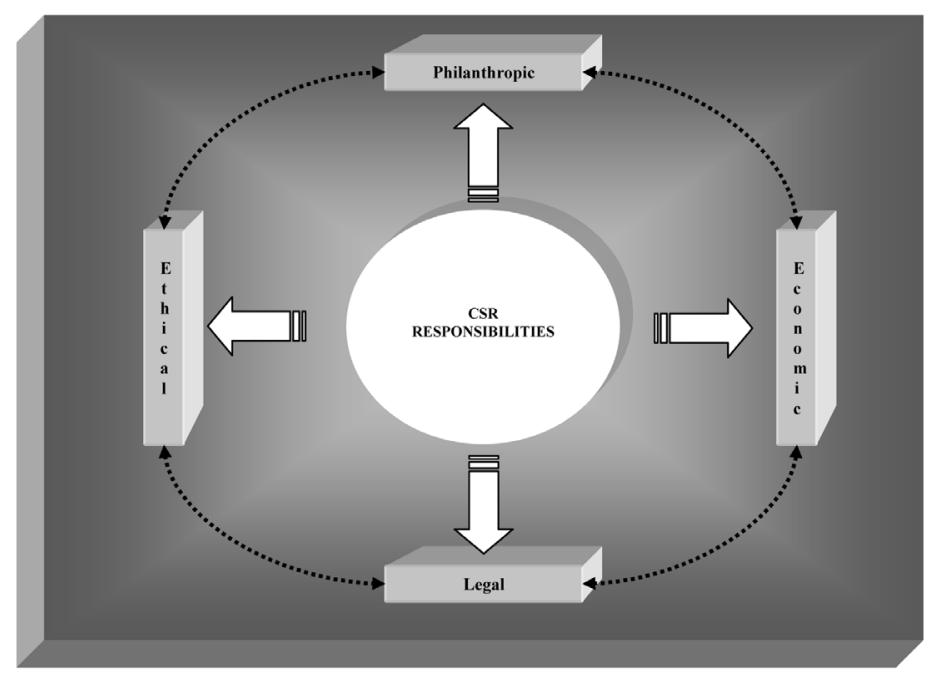

Figure 7. CSR responsibilities of the firm

Source: developed by author

As noted above, the two strands (CI or what the firm does and CSR or what the firm does for stakeholders) are integrated through policies, which all employees must comply with. Compliance is achieved through constant monitoring by senior management or through the appointment of a senior CSR executive employed specially to manage all ethics and CSR activities of the firm. In some firms, CSR executive are responsible for corporate affairs or corporate regulatory affairs as in the case of BAT which runs an integrative system similar to this. 


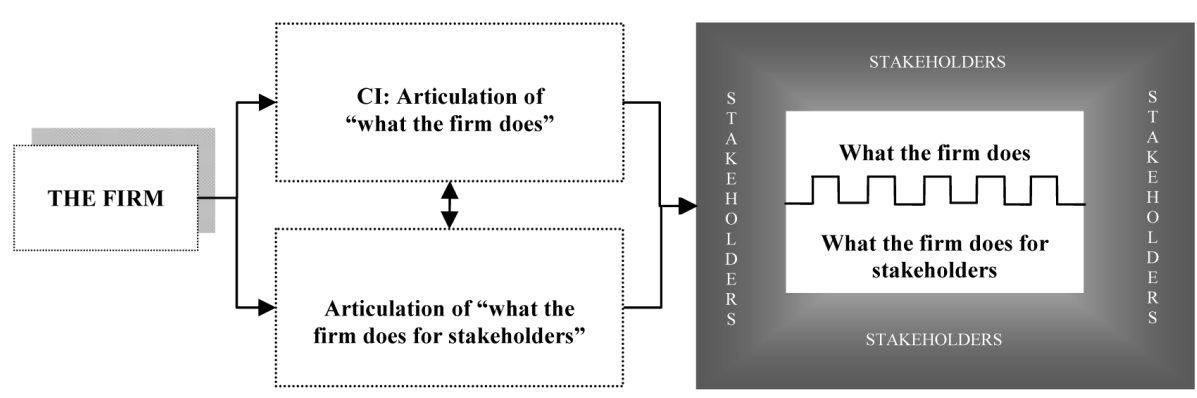

Figure 8. CSR identity framework

Source: developed by author

In some firms, CSR executive are responsible for corporate affairs or corporate regulatory affairs as in the case of BAT (British American Tobacco) which runs an integrative system similar to this. The corporate identity communication duties of Corporate Regulatory Affairs Managers at BAT is combined with the CSR responsibilities. It is the responsibility of these managers to ensure that employees at all levels observe all CSR policies in the course of all their daily activities. In some firms, CSR is integrated with corporate identity or "what the firm does" through the appointment of Ethics and CSR Monitoring officers in all departments. The role of these executives would be limited to the monitoring of ethics and CSR in their respective department or units. It must be noted however that the name and responsibilities adduced to CSR in various firms is highly dependent on the extent of their business activities. Two key issues determine this emphasis. The first is whether the firm is service-oriented or product-focused and second, whether the firm's key impacts are environmental, social, or economic.

In addition, the success and the extent of integration of CSR into corporate identity or "what the firm does" will be highly dependent on the power and authority designated to the position of the firm's CSR executive. While the Vice President (CSR) at Nike for instance is likely to have immense power and authority in the integration of CSR into corporate identity or "what the firm does", the activities of junior CSR staff reporting to mid-level managers may not have the same impact or influence. Importantly, the integration of corporate identity activities and CSR driven actions bring to life a new construct, which we call CSR Identity, which we define as: 


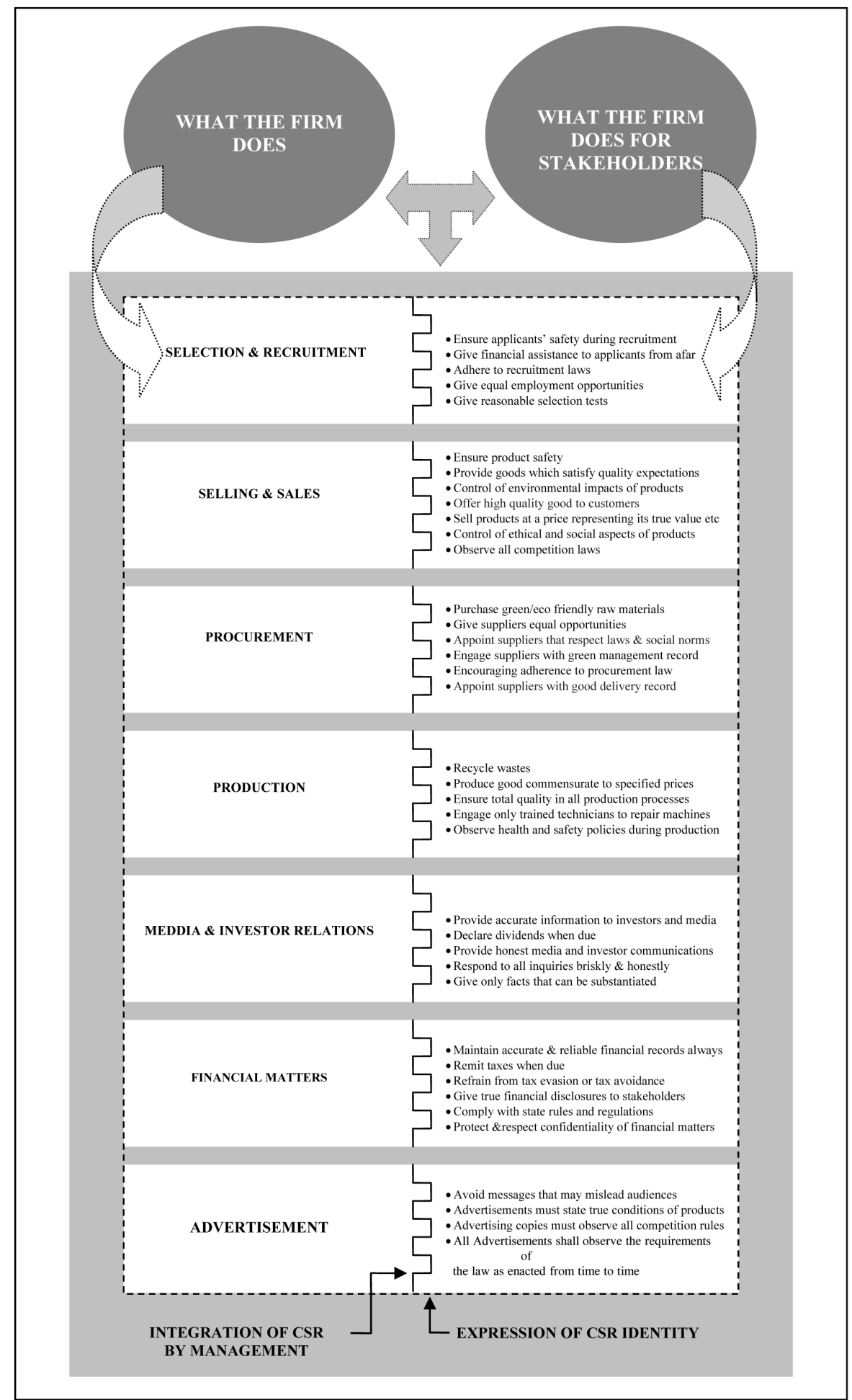

Figure 9. integration of "what the firm does"-"what the firm does for stakeholders"

Source: developed by author

CSR Identity is the articulation of 'what the firm does for stakeholders' (i.e. pursuit of ethical and socially responsible business behaviour, discharge of legal obligations to stakeholders, quest for social good, contribution of socioeconomic aids to the society) and the voluntary integration of these CSR concerns into 'what the firm does' (i.e. buying, selling, hiring, firing etc). This integration is then projected (intentionally or accidentally) to stakeholders through one or more elements of the corporate identity mix including corporate symbols, 
organisational structure, corporate culture, corporate strategy, corporate behaviour and through the formal lines of corporate communications.

\section{Discussion}

The outcome of this study corroborated the theoretical conception that there is a link subsisting between CSR and corporate identity (see Maignan and Ralston, 2002; Esrock and Leichty, 1998; Hooghiemstra, 2000; Adams et al. 1998). This conceptual study examined the meanings of corporate identity and CSR highlighting the notion of "what the firm does" and "what the firm does for stakeholders" as the point of convergence between the two constructs. The paper integrated these two constructs by bringing together various business activities namely procurement, marketing, production etc, which allow the expression of corporate identity and all economic, legal, ethical and philanthropic responsibilities of the firms to stakeholders. The integration of these responsibilities provides researchers with a good theoretical foundation to substantiate the link between CSR and corporate identity. Furthermore, we contribute towards the theoretical literature of corporate identity and CSR by developing a working definition for the CSR Identity construct.

Because this study is limited to the integration of "what the firm does" into "what the firm does for stakeholders", there is an opportunity in future to examine how other aspects of corporate identity such as what the firm is, where the firm is going and so on can be integrated into CSR. Clearly, this provides opportunity for future research.

\section{Conclusion}

In this article, we sought to integrate the concepts of corporate identity and CSR. We reviewed the meaning of CSR and corporate identity and identified various notions of corporate identity and CSR. We adopted the notion of "what the firm does", which highlights a firm's business activities and "what the firm does for stakeholders" as working definitions for corporate identity and CSR respectively; using these definitions as a means of establishing a link between these two concepts. The integration of these concepts began with the articulation of "what the firm does" and "what the firm does for stakeholders". These concepts were subsequently integrated through policy making. The integration of corporate identity activities and CSR oriented actions bring to life a new construct - CSR Identity. Thus, a definition highlighting the integration of CSR and identity was put forward to explicate its meaning.

\section{References}

Abratt, R., \& Kleyn, N. (2012). Corporate identity, corporate branding and corporate reputations reconciliation and integration. European Journal of Marketing, 46(7/8), 1048-1063. http://dx.doi.org/10.1108/03090561211230197

Al-Rahji, I., Altman, Y., Metacalfe, B., \& Roussel, J. (2006). Managing Impatriate Adjustment as a Core Human Resource Management Challenge. Human Resource Planning, 29(4).

Arthur, J. B. (1994). Effects of human resource systems on manufacturing performance and turn over. Academy of Management Journal, 37, 670-687. http://dx.doi.org/10.2307/256705

Assadourian, E. (2006). The State of Corporate Responsibility and the Environment. Georgetown International Environmental Law Review, 18(4).

Balmer, J. M. T. (2001). Corporate Identity, Corporate Branding, and Corporate Marketing: Seeing Through the Fog. European Journal of Marketing: Special Edition on Corporate Identity and Corporate Marketing, 34(3/4).

Balmer, J. M. T., \& Greyser, S. A. (2003). Revealing the Corporation. Perspectives on Identity, Image, Reputation, Corporate Branding and Corporate-level Marketing. Routledge, London.

Balmer, J. M. T., \& Greyser, S. A. (2006). Commentary Corporate marketing Integrating Corporate Identity, Corporate Branding, Corporate Communications, Corporate Image and Corporate Reputation. European Journal of Marketing, 40(7/8), 730-741. http://dx.doi.org/10.1108/03090560610669964

Barney, J. B., \& Wright, P. M. (1998). On becoming a strategic partner: The role of human resources in gaining competitive advantage. Human Resource Management, 37(1), 31-46. http://dx.doi.org/10.1002/(SICI)1099-050X(199821)37:1<31::AID-HRM4>3.0.CO;2-W

Brennan, L. L., \& Johnson, V. E. (2004). Technology Management for Corporate Social Responsibility. Technology and Society Magazine, 23(1), 40-48. http://dx.doi.org/10.1109/MTAS.2004.1273471 
Burchell, J., \& Cook, J. (2006). Confronting the "corporate citizen": Shaping is course of corporate social responsibility. The International Journal of Sociology and Social Policy, 26(3/4). http://dx.doi.org/10.1108/01443330610657188

Burgoon, M., Pfau, M., \& Thomas, S. Birk. (1995). An Inoculation Theory Explanation for the Effects of Corporate Issue/Advocacy Advertising Campaigns. Communication Research, 22(4), 485-505. http://dx.doi.org/10.1177/009365095022004006

Burke, L., \& Logsdon, J. M. (1996). How Corporate Social Responsibility Pays Off. Long Range Planning, 29(4). http://dx.doi.org/10.1016/0024-6301(96)00041-6

Cai, Y., Jo, H., \& Pan, C. (2012). Doing Well While Doing Bad? CSR in Controversial Industry Sectors. Journal of Business Ethics, 108, 467-480. http://dx.doi.org/10.1007/s10551-011-1103-7

Carroll, A. B. (1979). A three-dimensional conceptual model of corporate social performance. Academy of Management Review, 4, 497-505.

Carroll, A. B. (1991). The pyramid of corporate social responsibility: Toward the moral management of $\begin{array}{lllll}\text { organizational } & \text { stakeholders. } & \text { Business } & \text { Horizons, } & 34,48 .\end{array}$ http://dx.doi.org/10.1016/0007-6813(91)90005-G

Carroll, A. B., \& Buchholtz, A. K. (2002). Business and Society: Ethics and stakeholder management. Thomson - South Western.

Commission of the European Communities. (2001). Green Paper: Promoting a European framework for corporate social responsibility. Brussels: EU Commission.

Commission of the European Communities. (2002). Communication from the Commission concerning corporate social responsibility: A business contribution to sustainable development. Brussels: EU Commission.

Cutcher-Gershenfeld, J. (1991). The impact on economic performance of a transformation in industrial relations. Industrial and Labor Relations Review, 44, 241-260. http://dx.doi.org/10.2307/2524806

Davis, K. (1960). Can Business Afford to ignore social responsibilities? California Management Review, 2 , 70-76.

Davis, K., \& Blomstrom, R. L. (1966). Business and Its Environment. McGraw Hill, New York.

Dawkins, J., \& Stewart, L. (2003). CSR in Stakeholder Expectations: And Their Implication for Company Strategy. Journal of Business Ethics, 44, 2-3. http://dx.doi.org/10.1023/A:1023399732720

De George, R. T. (1999). Business Ethics (5th ed.). Prentice Hall, Upper Saddle River, NJ.

Deephouse, D. L., \& Carter, S. M. (2005). An Examination of Differences Between Organizational Legitimacy and Organizational Reputation. Journal of Management Studies, 42(2), 329-360. http://dx.doi.org/10.1111/j.1467-6486.2005.00499.x

Dolphin, R. (2003). The Corporate Communication Function: How well is it Funded? Corporate Communications: An International Journal, 8(1), 5-10. http://dx.doi.org/10.1108/13563280310458867

Doyle, P. (1995). Marketing in the new millennium. European Journal of Marketing, 29(13), 23-41. http://dx.doi.org/10.1108/03090569510147712

Driver, M. (2006). Beyond the Stalemate of Economics versus Ethics: Corporate Social Responsibility and the Discourse of the Organizational Self. Journal of Business Ethics, 66, 337-356. http://dx.doi.org/10.1007/s10551-006-0012-7

Fombrun, C., \& Rindova, V. (2000). The road to transparency: reputation management at Royal Dutch/Shell. In Schultz, M., Hatch, M. J., \& Holten Larsen, M. (Eds.), The Expressive Organisation. Linking Identity, Reputation and the Corporate Brand. Oxford University Press, Oxford.

Gond, Jean-Pascal \& Olivier Herrbach. (2006). Social Reporting as an Organisational Learning Tool? A Theoretical Framework. Journal of Business Ethics, 65, 359-371. http://dx.doi.org/10.1007/s10551-006-6405-9

Goodman, M. B. (2000). Corporate communication: the American picture. Corporate Communications: An International Journal, 5(2), 69-74. http://dx.doi.org/10.1108/13563280010372496 
Goodman, M. B. (2006). Corporate communication practice and pedagogy at the dawn of the new millennium. Corporate Communications: An International Journal, 11(3), 196-213. http://dx.doi.org/10.1108/13563280610680803

Grayson, D., \& Hodges, A. (2007). Corporate Social Opportunity! Seven Steps to Make Corporate Social Responsibility work for Your Business. Retrieved from http://www.rentonjames.com/downloads/cso_00prelims.pdf

Griffin, A., \& Hauser, J. R. (1993). The Voice of the Customer. Marketing Science, 12(1), 1-27. http://dx.doi.org/10.1287/mksc.12.1.1

Grönroos, C. (1997). From marketing mix to relationship marketing-towards a paradigm shift in marketing, Keynote paper. Management Decision, 35(4), 322-339. http://dx.doi.org/10.1108/00251749710169729

Haines, M. N., Goodhue, D. L., \& Gattiker, T. F. (2006). Fit Between Strategy and IS Specialization: A Framework for Effective Choice and Customization of Information System Application Modules. Information Resources Management Journal, 19(3), 34-47. http://dx.doi.org/10.4018/irmj.2006070103

He, H. W., \& Balmer, J. M. T. (2005). The Salience and Significance of Generic Identity: An Exploratory Study of UK Building Societies. International Journal of Bank Marketing. http://dx.doi.org/10.1108/02652320510603951

Heene, Jan Lepoutre Aime. (2006). Investigating the Impact of Firm Size on Small Business Social Responsibility: A Critical Review. Journal of Business Ethics, 67, 257-273. http://dx.doi.org/10.1007/s10551-006-9183-5

Humphreys, P., \& Mclvor, M. E. (1998). The purchasing function as a professional service firm: implications for training and development. Journal of European Industrial Training, 22(1). http://dx.doi.org/10.1108/03090599810197630

Huselid, A., Susan E., Jackson, R., \& Schuler, S. (1997). Technical and Strategic Human Resource Management Effectiveness as Determinants of Firm Performance Mark. The Academy of Management Journal, 40(1), 171-188. http://dx.doi.org/10.2307/257025

Huselid, M. A. (1995). The impact of human resource management practices on turnover, productivity, and corporate financial performance. Academy of Management Journal, 38, 635-672. http://dx.doi.org/10.2307/256741

Huselid, M. A., \& Becker, B. E. (1996). Methodological issues in cross-sectional and panel estimates of the human resource-firm performance link. Industrial Relations, 35, 400-422. http://dx.doi.org/10.1111/j.1468-232X.1996.tb00413.x

Ibrahim, N. A., Angelidis, J. P., \& Howard, D. P. (2006). Corporate Social Responsibility: A Comparative Analysis of Perceptions of Practising Accountants and Accounting Students. Journal of Business Ethics, 66(2/3), 157. http://dx.doi.org/10.1007/s10551-005-5572-4

Jaworski, B. J., \& Kohli, A. K. (1993). Market Orientation: Antecedents and Consequences. Journal of Marketing, 57(3), 53-70. http://dx.doi.org/10.2307/1251854

Jenkins, H. (2006). Small Business Champions for Corporate Social Responsibility. Journal of Business Ethics, 67, 241-256. http://dx.doi.org/10.1007/s10551-006-9182-6

Johnson, P. F., Leenders, M. R., \& McCue, C. (2003). A comparison of purchasing's organizational roles and responsibilities in the public and private sector. Journal of Public Procurement, 3(1).

Jones, P., Comfort, D., Hillier, D., \& Eastwood. (2005). Corporate social responsibility: a case study of the UK's leading food retailers. British Food Journal, 107(6).

Karna, J., Hansen, E., \& Juslin, H. (2003). Social responsibility in environmental marketing planning. European Journal of Marketing, 37(5/6). http://dx.doi.org/10.1108/03090560310465170

Ker-Tah, H. (2012). The advertising effects of corporate social responsibility on corporate reputation and brand equity: evidence from the life insurance industry in Taiwan. Journal of Business Ethics, 109, 189-201. http://dx.doi.org/10.1007/s10551-011-1118-0

Kiriakidou, O., \& Millward, L. J. (1999). Corporate Identity: External Reality or Internal Fit. International Centre for Corporate Identity Studies. Working Paper Series. University of Strathclyde. 
Kolk, A. (2005). Environmental Reporting By Multinationals from the Triad: Convergence or Divergence? Management International Review, 45.

Kotler, P. (2000). Marketing Management. New Jersey: Prentice Hall.

Lantos, G. P. (2001). The boundaries of strategic corporate social responsibility. Journal of Consumer Marketing, 18(2), 595 - 630. http://dx.doi.org/10.1108/07363760110410281

Maignan, I., Ferrell, O. C., \& Ferrell, L. (2005). A stakeholder model for implementing social responsibility in marketing. European Journal of Marketing, 39(9/10). http://dx.doi.org/10.1108/03090560510610662

Maloni, M. J., \& Brown, M. E. (2006). Corporate Social Responsibility in the Supply Chain: An Application in the Food Industry. Journal of Business Ethics, 68, 35-52. http://dx.doi.org/10.1007/s10551-006-9038-0

Manuel Castelo BrancoLúcia Lima Rodrigues. (2006). Corporate Social Responsibility and Resource Based Perspectives. Journal of Business Ethics, 69(2), 111. http://dx.doi.org/10.1007/s10551-006-9071-z

Melewar, T. C., Bassett, K., \& Simo es, C. (2006). The role of Communication and Visual Identity in Modern Organisations. Corporate Communications: An International Journal, 11(2), 138-147. http://dx.doi.org/10.1108/13563280610661679

Mintzberg, H., \& Quinn, J. B. (2000). The Strategy Process. Englewood Cliffs, NJ.

O'Brien, D. J. (2001). Integrating Corporate Social Responsibility with Competitive Strategy. Best MBA Paper in Corporate Citizenship, The Centre for Corporate Citizenship, Mack Robinson College of Business, Georgia State University.

Olasz, C. S. (2006). Marketing's role in a relationship age. Baylor Business Review, 24(2).

Olins, W. (1995). The New Guide To Identity: How to Create and Sustain Change Through Managing Identity. Aldershot, London.

Owen, D. L., Swift, T. A., Humphrey, C., \& Bowerman, M. (2000). The new social audits: accountability, managerial capture or the agenda of social champions? European Accounting Review, 9(1). http://dx.doi.org/10.1080/096381800407950

Perrini, F. (2006). SMEs and CSR Theory: Evidence and Implications from an Italian Perspective. Journal of Business Ethics, 67, 305-316. http://dx.doi.org/10.1007/s10551-006-9186-2

Phillips, E. D. (2006). Corporate Social Responsibility in Aviation. Journal of Air Transport, 11(1), 65.

Prahalad, C. K., \& Hamel, G. (1989). Strategic Intent. Harvard Business Review, Massachusetts.

Ries, A. L., \& Trout, J. (1986). Positioning: The Battle for your Mind. McGraw-Hill, London.

Robins, F. (2005). The Future of Corporate Social Responsibility. Asian Business and Management, 4(2), 5. http://dx.doi.org/10.1057/palgrave.abm.9200125

Salu, A. O. (1994). Understanding Public Relations. Talkback Publishers Limited, Lagos.

Schmidt, K. (1995). The Quest For Identity. Cassell, London.

Schoemaker, P. J. H., \& Amit, R. (1994). Investment in strategic assets: Industry and firm level perspectives. Advances in Strategic Management, 10, 3-33.

Schumann, David, W., Hathcote, Jan, M., \& West, S. (1999). Corporate Advertising in America: A Review of Published Studies on Use, Measurement and Effectiveness. Journal of Advertising, 20(3).

Shu-pel, T. (2008). Corporate marketing management and corporate-identity building. Marketing Intelligence and Planning, 26(6), 621-633. http://dx.doi.org/10.1108/02634500810902866

Siltaoja, M. E. (2006). Value Priorities as Combining Core Factors Between CSR and Reputation -A Qualitative Study. Journal of Business Ethics, 68, 91-111. http://dx.doi.org/10.1007/s10551-006-9042-4

Soni, S., Sharma, J. P., \& Makarand Upadhyaya. (2009). Communicating corporate identity for the hotel industry. Journal of Marketing \& Communications, 4(3), 53-58.

Stuart, H. (1998). Exploring the corporate identity/corporate image and corporate Reputation. Long Range Planning, 31(5), 695-702.

Suvatjis, J. Y.,\& de Chernatony, L. (2004). Corporate Identity Modelling: A Review and Presentation of the Six Station Model for Corporate Identity. Working paper. Centre for Research in Brand Marketing, Birmingham Business School, The University of Birmingham, Winterbourne, Edgbaston, Birmingham. 
Swanson, D. L. (1999). Toward an Integrative Theory of Business and Society: A Research Strategy for Corporate Social Performance. The Academy of Management Review, 24(3), 506-521.

The World Bank Group. (2004). Corporate Social Responsibility. Retrieved from www.worldbank.org/developmentcommumcations/wherel/environment/csr.htm

Topalian, A. (1984). Corporate Identity: Beyond the Visual Overstatements. International Journal of Advertising, $3,55-62$.

Vos, J. F. J. (2003). Corporate social responsibility and the identification of stakeholders. Corporate Social Responsibility and Environmental Management, 10(3), 141. http://dx.doi.org/10.1002/csr.39

Wallace, J., Tassabehji, R., \& Cornelius, N. (2006). A Statistical Analysis of Corporate Social Responsibility, Corporate Identity and Ethics Teaching in Business Schools. Working Paper, No 06/17, June, School of Management, University of Bradford.

WBCSD. (1999). Corporate Social Responsibility. Meeting Changing Expectations. Conches-Geneva. Retrieved from www.wbcsd.org

Whetten, D. A., Rands, G., \& Godfrey, P. (2002). What are the responsibilities of business to society? In A. Pettigrew, H. Thomas \& R. Whittington (Eds.), Handbook of strategy and management. Sage, London.

Whitehouse, L. (2006). Corporate Social Responsibility: Views from the Frontline. Journal of Business Ethics, 63, 279-296. http://dx.doi.org/10.1007/s10551-005-3243-0

Williamson, O. E., \& Winter, S. G. (1993). The Nature of the Firm: Origins, Evolution and Development. Oxford University Press, London.

Worthington, I., Monder, R.,\& Jones, T. (2006). Exploring Corporate Social Responsibility in the U.K. Asian Small Business Community. Journal of Business Ethics, 67(2), 201. http://dx.doi.org/10.1007/s10551-006-9024-6

Zsolnai, L. (2002). New Agenda for Business Ethics. In L. Zsolnai (Ed.), Ethics in the Economy. Handbook of Business Ethics (pp. 1-7). Peter Lang Academic Publisher, Oxford and Bern.

\section{Appendix}

\section{Definitions of corporate identity}

\section{Author Definition}

Pilditch (1970): Corporate identity will identify and express the personality of corporations as it will be when the scheme is substantially in use".

Selame and Selame (1975): The firm's visual statement to the world of who and what the company is, of how the company views itself and therefore, has a great deal to do with how the world views the company.

Margulies (1977): The sum of all the ways a company chooses to identify itself to all its publics-the community, customers, employees, the press, present and potential stockholders, security analysts and investment bankers.

Olins (1978): The tangible manifestation of a corporate personality is a corporate identity. It is the identity that projects and reflects the reality of the corporate personality. Sometimes as we know, the corporate identity is introduced as a catalyst to encourage the development of a corporate personality; sometimes it reflects not what is, but what the corporation will like to be.

Birkight and Stadler (1980): Visuals of an organisation.

Henrion (1980): It embodies all visual expressions, also all non-visual expression and behaviour in the social, economic and political field.

Carter (1982): Corporate identity is the logo or brand image of a company and all other visual manifestations of the identity of a company.

Hannebohn and Blocker (1983): Corporate identity is the strategy that helps to increase the economic performance and efficiency of a company. It co-ordinates achievements, values and information, and leads to integration in the sense of corporation.

Topalian (1984): Corporate identity articulates what the firm is, what it stands for and what it does. Corporate identities are projected and are largely under the control of host organisations. 
Albert and Whetten (1985) It is that which is central, enduring, and distinct about an organisation's character.

Antonoff (1985): Corporate identity is the sum of all methods of portrayal, which the company uses to present itself to employees, providers of capital, and the public. According to organisational units, corporate identity is the total of all typical and harmonised methods of portrayal of design, culture and communication.

Lux (1986): Corporate identity is the expression of the personality of a company that can be experienced by anyone. It is manifested in the behaviour and communication of the company and it is aesthetic, formal expression; it can be measured as perceptual result amongst internal and external target groups.

Downey (1986): Corporate identity is the sum of all factors that define and project what an organisation is and where it is going-its unique history, business mix, management style, communication policies and practices, nomenclature, competencies and market and competitive distinction.

Portugal and Halloran (1986): The comprehensive and orchestrated presentation of what a corporation is, where it is going, and how it is different. It facilitates the communication of a corporation's strategic commitments, business competencies, market participants, competitive positioning, organisational character, and standards of performance.

Birkight and Stadler (1986): Corporate identity is the strategically planned and operationally applied internal and external self-presentation and behaviour of a company. It is based on an agreed company philosophy, long term goals and in particular a desired image, combined with the will to utilise all instruments of the company as one unit, both internally and externally.

Tannebeger (1987): Corporate identity reflects the distinctive capability and the recognisable individual characteristics of the company. Identity, in this sense, also includes the distinction and recognition of parts of the whole company and the attribution of those parts to the whole.

Ackerman (1988): It is the unique capability of a company that is the cross-functional mix of experience, skills knowledge and talents-which distinguish the corporation and determine its ability to create value in proprietary ways (Ackerman 1988).

Carls (1989): Corporate identity is "active" and visual consistency is more about "attitude" than a rigid set of values. The corporate identity programme is a series of compatible but non-uniform images.

Abratt (1989): It is a set of visual cues-physical and behavioural that makes a firm recognisable and distinguishes it from others. These cues are used to represent or symbolise the company.

Olins (1989): Corporate identity is the tangible manifestation of the personality of a company. It is identity that reflects and projects the real personality of a company.

Lambert (1989): Identity includes all distinct manifestations of a firm.

Olins (1990): Corporate identity consists of explicit management of the sum or all ways in which company's activities are perceived. It can project three things: who you are, what you do and how you do it.

Smythe et al. (1992): Corporate identity is an organisation's name representing its parts, subsidiaries and brands and how these interrelate. It is a visual style as expressed through its products, printed materials including packaging and stationery, its working environments and livery of its staff, vehicles, etc. It is an entity, which may also include the behaviour of employees and the styles of language used by employees.

Balmer (1993): It is a fusion of strategy, behaviour (culture) and communication. It is not the preserve of any management discipline, but instead draws from several. It comes into being when there is a common ownership of an organisation's philosophy.

Blauw (1994): Corporate identity is the total of visual and non-visual means applied by a company to present itself to all its relevant target groups on the basis of a corporate identity plan.

Schmidt et al. (1995): Corporate identity is the degree to which a firm achieves a distinct and a coherent image in its aesthetic output

Olins (1995): Every organisation carries out thousands of transactions every day: it buys, it sells, it hires and fires, it makes, it cleans, it promotes through advertising and other publicity-and so on. In all these, these transactions, the organisation will in some way be presenting itself or part of itself to the various groups of people with whom it deals. The totality of the way an organisation presents itself can be called identity (Olins 1995). 
van Riel (1995): The manifestation of a bundle of characteristics, which form a kind of shell around the organisation, displaying its personality.

van Rekom (1997): The set of meanings by which an object allows itself to be known and through which it allows people to describe, remember and relate to it.

van Riel and Balmer (1997): It indicates the ways a company presents itself through behaviour as well as through symbolism, to internal and external audiences. It is rooted in the behaviour of individual firm members, expressing the firm's "sameness over time", "distinctness" and "centrality".

Balmer and Soenen (1997): It encompasses three core dimensions: the mind, the soul, and the voice. The mind is the product of conscious decisions, the soul results from subjective elements such as the firm's distinct corporate values and the sub-cultures present in the firm. The voice represents the way a firm communicates.

Leuthesser and Kohli (1997): It is the way an organisation reveals its philosophy and strategy through communication, behaviour and symbolism.

Marwick and Fill (1997): The firm's framing of itself to stakeholders and ways it distinguishes itself from all other firms, through a variety of cues. It represents how the organisation would like to be perceived and can include corporate identity programmes, advertising, dress codes and the standard of customer contact. Some of the cues will focus on visual identity. Some will focus on behaviour.

International Corporate Identity Group (1997): Every organisation has an identity. It articulates the corporate ethos, aims and values and presents a sense of individuality that can help to differentiate the organisation within its competitive environment. When well managed, corporate identity can be a powerful means of integrating the many disciplines and activities essential to an organisation's success. It can also provide the visual cohesion necessary to ensure that all corporate communications are coherent with each other and result in an image consistent with the organisation's defining ethos and character. By effectively managing its corporate identity an organisation can build understanding and commitment among its diverse stakeholders. This can be manifested in an ability to attract and retain customers and employees, achieve strategic alliances, gain the support of financial markets and generate a sense of direction and purpose. Corporate identity is a strategic issue. Corporate identity differs from traditional brand marketing since it is concerned with all of an organisation's stakeholders and the multi-faceted way in which an organisation communicates.

Hatch and Schultz (1997): We view organisational identity as grounded in local meanings and organisational symbols and thus embedded in organisational culture, which we see as the internal symbolic context for the development and maintenance of organisation identity. The symbolic construction of corporate identity is communicated to organisational members by top management, but is interpreted and enacted by organisational members based on the cultural patterns of the organisation, work experiences and social influence from external relations on the environment. Thus, organisational identity emerges from the ongoing interactions between organisational members (including middle-level managers) as well as from top management influence. Furthermore, we argue that as the internal-external distinction collapses, organisational identity is increasingly influenced by (and becomes an influence on) organisational image.

Moingeon and Ramanantsoa (1997): It is a set of interdependent characteristics that gives an organisation specificity, stability and coherence, thus making it identifiable. These characteristics alone do not make it possible to identify an organisation. It is the configuration or pattern of the system that establishes the uniqueness of the organisation, which plays a significant role.

Gray and Balmer (1998): Corporate identity is the reality of an organisation. It is the distinct characteristics of the firm.

Fiol, Hatch and Golden-Biddle (1998): An organisational identity is the aspect of culturally embedded sense making that is self-focussed. It defines who we are in relation to the larger social system to which we belong. Identity is affected by organisational culture and so by other meaning-making systems with which the self interacts.

Gioia (1998): Organisational identity is (a) what is taken by the organisation; (b) what makes the organisation distinctive from other organisations (at least in the eyes of the beholding members); and (c) what is perceived by members to be an enduring or continuing feature.

Hawn (1998): Identity is what the firm is. Image is how the firm is perceived. A corporate identity programme is the visual melding of identity and image. 
Leitch (1999): Both corporate identity and "logo centrism" see identity as something that can be constructed, therefore, controlled by the firm.

Dolphin (1999): Identity concerns the presentation of the corporate persona. Unlike image, identity does not change from one audience to another until the time it is altered, it remains consistent. Corporate identity is not corporate image. Corporate identity is the individuality of the organisation. The way that it actually is, in short, corporate personality.

Balmer and Dinnie (1999): A powerful corporate identity enhances the likelihood of identification or bonding with the organisation. This applies both to internal and external target groups.

Gioia et al. (2000): It is the consistent and targeted representation of the firm, with emphasis on corporate symbol and logos. It is strategic and applied both internally and externally.

Kiriakidou and Millward (2000): Corporate identity is the tangible representation of the organisational identity, the expression as manifest in the behaviour and communication of the organisation.

Shultz and Holten-Larsen (2000): Visual and strategic schools of thought.

Alessandri (2001): Corporate identity is a firm's strategically planned and purposeful presentation of itself in order to gain a positive corporate image in the minds of the public. A corporate identity is established in order to gain a favourable corporate reputation over time. It is all of the observable and measurable elements of a firm's identity manifest in its comprehensive visual presentation of itself, including, but not limited to, its name, logo, tagline, colour palette and architecture. Corporate identity also includes the firm's public behaviour, including, but not limited to, its reception of employees, customers, shareholders and suppliers.

Korver and van Ruler (2003): It is self-presentation to stakeholders through symbolism, communication and behaviour. Corporate identity can be seen as the way in which a company makes itself known to the world. Behaviour, communication and symbols are its indicators.

Davies et al. (2003): Identity is what holds a group together, the corporate glue, a sense of belonging, the informal and formal set of rules that we abide by, an understanding of who can join. Identity is socially constructed. It does not exist but is created through our interaction with other organisation members. It may be formalised in part by a company history, rulebooks, terms and conditions of employment and documents such as the mission and vision statement, but it is still difficult to encapsulate in any formal way.

Melewar and Karaosmanoglu (2006): Corporate identity is the presentation of an organisation to every stakeholder. It is what makes an organisation unique and it incorporate the organisation's communication, design, culture, behaviour, structure, industry identity and strategy. It is thus intrinsically related to both the corporate personality and image. 